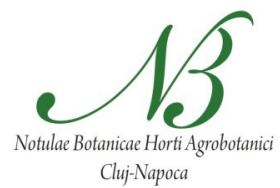

\title{
Effects of Dual/Threefold Rootstock Grafting on the Plant Growth, Yield and Quality of Watermelon
}

\author{
Yaoguo $\mathrm{QIN}^{1}$, Cuiqin YANG ${ }^{2}$, Jialong XIA ${ }^{1}$, Jing $\mathrm{HE}^{1}$, Xiaoli $\mathrm{MA}^{1}$, Chuanyang $\mathrm{YANG}^{1}$, \\ Yangxia ZHENG ${ }^{1}$, Xia LIN $^{1}$, Zhongqun $\mathrm{HE}^{1}$, Zhi HUANG ${ }^{1}$, Zesheng YAN ${ }^{1 *}$ \\ 'Sichuan Agricultural University, College of Horticulture, No.46 Xinkang Road, Ya'an 625014, China; 863748012@qq.com ("corresponding author) \\ ${ }^{2}$ Sichuan Agricultural University, College of Agriculture, No. 211 Huimin Road, Chengdu 611130, China
}

\begin{abstract}
To test the feasibility of multi-rootstock grafting, bottle gourd and pumpkin were used as rootstocks in a comparative analysis of the effects of single, dual, and threefold rootstock grafting on the plant growth, fruit yield, and quality of watermelon. Results showed that different grafts have significant effects on the abovementioned properties. The appropriate dual/threefold rootstock grafting allowed for higher survival rates. The combined rootstock of bottle gourd and pumpkin can enhance the plant growth potential and lower the incidence of wilt. The single fruit weight of the grafted plants with a combined rootstock from bottle gourd and pumpkin was the median of the weights obtained with the pumpkin rootstock and the bottle gourd rootstock. The plot yield of grafted plants with a pumpkin rootstock was higher than that of the plants with a bottle gourd rootstock. The low soluble solids content of the fruit grafted with a pumpkin rootstock had relatively high acidity, which could be improved by adding bottle gourd to the rootstock. The vitamin $\mathrm{C}$ content of the grafted fruit from the combined bottle gourd and pumpkin rootstock was higher than that of plants grafted with either bottle gourd or pumpkin alone. The subsequent analysis showed that the combined rootstock of bottle gourd and pumpkin has significant or extremely significant interaction effects on the stem diameter, number of leaves, single fruit weight, plot yield, and fruit vitamin C content of the grafted watermelon plants, which probably led to the higher related index values of some of grafting combinations.
\end{abstract}

Keywords: dual rootstock, grafting, rootstock, threefold rootstock, watermelon

\section{Introduction}

Watermelon (Citrullus lanatus (Thunb.) Matsum. et Nakai) is a key horticultural crop of the gourd family (Cucurbitaceae) that is widely cultivated. Given its intolerance to continuous cropping, soil-borne diseases such as wilt are serious. These diseases affect the growth of watermelon plants, as well as the uptake of water and fertilizer, thereby decreasing the yield and fruit quality (Davis et al., 2008b). Many studies show that grafting of watermelon is an effective tool to overcome continuous cropping obstacles and control soil-borne diseases (Lee, 1994; Miguel et al., 2004; Paroussi et al., 2007; Rouphael et al., 2010; Yetisir et al., 2003b). A suitable rootstock for grafting is a key factor for improving the grafting survival rate and guaranteeing the yield and quality of watermelon. Current rootstock types that have been applied in watermelon production include bottle gourd (Lagenaria siceraria (Molina) Standl.) and pumpkin (Cucurbita moschata Duch. ex Poir.). It has been reported that plant growth, fruit yield and quality such as sugar, $\mathrm{pH}$, flavor and other health-related compound content can be affected by grafting and the type of rootstock used (Alan et al., 2007; Chouka and Jebari, 1999; Yetisir et al., 2003b). Changes in the scion are controlled by the rootstock through controlled uptake, synthesis, and translocation of water, minerals, and plant hormones (Lee and Oda, 2002). Reports vary on whether grafting effects are advantageous or deleterious, but it is usually agreed that the scion/rootstock combination must be carefully chosen for optimal fruit quality (Davis $e t$ al., 2008a) and high yield.

The effect of grafting greatly depends on the grafting compatibility and symbiotic affinity. Only the scion/rootstock combination with high levels of both properties can ensure high survival rate and normal growth of the grafted seedling with normal bearing fruits and without undesirable phenomena. Conventional grafting methods use single rootstock grafting. Several rootstocks are highly unique or specific because of the limited number of available germplasm resources. High resistance and excellent fruit quality after grafting seem impossible to achieve. The biological differences between the rootstock and scion account for the fact that a one-to-one correspondence 
between these plants is not necessarily the optimum combination for building a symbiotic relationship. When multiple rootstocks are used, especially with the complementary differences between rootstocks, the dual/threefold rootstock grafting method can simultaneously increase the resistance and yield, as well as improve the fruit quality. Thus, this method is of great significance on the relatively benign industrial development of watermelon production.

Previous studies have reported the effects of dual rootstock grafting on the growth, yield, and fruit quality of cucumber. These studies indicated that dual rootstock grafting can enhance the growth potential of cucumber plants and promote the uptake of water and fertilizer. The single fruit weight and the soluble sugar content in fruit were higher with double rootstock grafting than with single rootstock grafting or in self-rooted plants (Chu et al., 2010). Specific dual rootstock combinations produced significantly higher yield than single rootstock grafting (Wang et al., 2011). Most studies on watermelon grafting focused on the effects of different single rootstock varieties on the growth, disease resistance, yield, and fruit quality of the grafted plant. To the best of our knowledge, the effects of $\mathrm{dual} /$ threefold rootstock grafting on the yield and quality of watermelon have not been previously reported.

The present experiment adopted bottle gourd and pumpkin as rootstocks and explored their effects on the survival rate, plant growth, yield, and quality of watermelon. The effects of grafting with different numbers and combinations of rootstocks were studied. The feasibility of multi-rootstock grafting and the complementation of differences between multiple rootstocks were assessed to find the optimal scion/rootstock combination and to provide a theoretical guide for their application in watermelon production.

\section{Materials and methods}

The tested rootstocks were the 'Zao Sheng Xi Zhen' cultivar of pumpkin and the 'Xi Ye' cultivar of bottle gourd. The tested scion was the 'Zao Jia' cultivar of watermelon. The seeds were provided by the Sichuan Seed Company.

\section{Seedling production}

The bottle gourd seeds were soaked and pregerminated on March 16, 2013, whereas the pumpkin seeds were soaked and pregerminated on March 18, 2013. All the seeds were sown after they germinated. The single rootstocks were prepared and sown in 32-plug trays. The dual rootstocks were sown in $6.5 \mathrm{~cm} \times 6.5 \mathrm{~cm}$ nutrition pots, whereas the threefold rootstock were in $9 \mathrm{~cm} \times 9 \mathrm{~cm}$ nutrition pots. Each tray or pot was covered with a thin plastic film after sowing, and the trays and pots were left uncovered after the seeds had sprouted. The scions were sown on March 20 after seed pregerminating. Grafting was commenced once the rootstocks had grown one leaf and one root tip and the cotyledons of the scion had spread.

\section{Grafting methods}

Single rootstock grafting method: A single plant of the rootstock was selected. One cotyledon was cut off and its growth point was obliquely sliced downward with a blade, such that the bevel cut and the vertical direction formed a $30^{\circ}$ angle. The section length should be $0.5 \mathrm{~cm}$. At a point $1 \mathrm{~cm}$ away from the scion cotyledon, the hypocotyl was obliquely cut downward to form a $30^{\circ}$ angle with the vertical direction. The length of this section should be equal to the rootstock length. The sections of the rootstock and scion were then closely aligned and fit together. A $1 \mathrm{~cm}$-wide plastic sheet was used to bundle both sections together, which was fixed in place with grafting clips.

Dual rootstock grafting method: One cotyledon was cut off and the corresponding growing point was sliced for each of the two rootstocks with a blade, using a method similar to that of single rootstock grafting. At a point $1 \mathrm{~cm}$ away from the scion cotyledon, cuts were made at the two opposite sides of the hypocotyledonary axis by an angle of $30^{\circ}$ to form a wedge with two symmetrical sections. Each had the same length as the rootstock. All sections were aligned and fit together, such that the sections of the two rootstock plants and two sections of one scion plant were close together. A $1 \mathrm{~cm}$-wide plastic sheet was used to bundle both sections together, which was fixed in place with grafting clips.

Threefold rootstock grafting method: One cotyledon was cut off and the corresponding growing point was sliced for each of the three rootstocks with a blade, using a method similar to that of single rootstock grafting. At $1 \mathrm{~cm}$ from the scion cotyledon, the hypocotyledonary axis was evenly cut into three sides, with each of the sections forming a $30^{\circ}$ angle with the vertical direction. The section lengths were equal to the rootstock length. All sections were aligned and fit together, such that the sections of the three rootstock plants and three sections of one scion plant were close together. A $1 \mathrm{~cm}$-wide plastic sheet was used to bundle both sections together, which was fixed in place with grafting clips.

\section{Grafted treatments}

The experiment used 10 grafted treatments listed in Tab. 1.

Each treatment contained grafting of 100 plants, and the experiment was performed with three replicates using a completely randomized design.

\section{Field planting and field management}

Perennial watermelon and a parcel of land with uniform soil fertility at the farmstead of Sichuan Agricultural University were chosen for planting in open field. For each $667 \mathrm{~m}^{2}$ field, $2500 \mathrm{~kg}$ organic fertilizer, $30 \mathrm{~kg}$ superphosphate, and $10 \mathrm{~kg}$ potassium sulfate were applied as the base fertilizer, and each plant was separated by a ridge for every $2.5 \mathrm{~m}$ row spacing. The field planting of the three-leaf-one-tip grafted seedling was finished on May 3, 2013. The row spacing was $0.4 \mathrm{~m} \times 2.5 \mathrm{~m}$, and the plot area was $20 \mathrm{~m}^{2}$, with 20 plants in each plot arranged in a randomized block design with 3 replications. While the plants were in bloom and bearing fruits, pruning or training of the plant is needed to select a fruit that will be eaten after bearing and to finish the topdressing and watering.

\section{Testing indexes and methods}

On day 20 after grafting, the survival rate of each grafted plant was tested. During the peak season for fruit growth, 10 plants were randomly selected from each plot for testing the stem diameter and the number of leaves. A portable chlorophyll fluorometer (PAM-2500, Walz, Germany) was used to test the Fv/Fm and $\Phi$ PSII values of the leaves during 
Tab. 1. Different grafted treatments in this experiment

\begin{tabular}{lll}
\hline Code & Treatment & \multicolumn{1}{c}{ Description } \\
\hline $\mathrm{T}_{1}$ & 1 watermelon/1 bottle gourd & $\begin{array}{l}\text { One watermelon plant was grafted onto one bottle gourd plant that } \\
\text { functioned as its rootstock. }\end{array}$ \\
\hline $\mathrm{T}_{2}$ & 1 watermelon/1 pumpkin & $\begin{array}{l}\text { One watermelon plant was grafted onto one pumpkin plant that } \\
\text { functioned as its rootstock. }\end{array}$ \\
$\mathrm{T}_{3}$ & 1 watermelon/1 bottle gourd +1 pumpkin & $\begin{array}{l}\text { One watermelon plant was simultaneously grafted onto one bottle gourd } \\
\text { plant and one pumpkin plant as its two rootstocks. }\end{array}$ \\
$\mathrm{T}_{4}$ & 1 watermelon/2 bottle gourd & $\begin{array}{l}\text { One watermelon plant was simultaneously grafted onto two bottle gourd } \\
\text { plants as its two rootstocks. }\end{array}$ \\
\hline $\mathrm{T}_{5}$ & 1 watermelon $/ 2$ pumpkin & $\begin{array}{l}\text { One watermelon plant was simultaneously grafted onto two pumpkin } \\
\text { plants as its two rootstocks. }\end{array}$ \\
$\mathrm{T}_{6}$ & 1 watermelon/1 bottle gourd +2 pumpkin & $\begin{array}{l}\text { One watermelon plant was simultaneously grafted onto one bottle gourd } \\
\text { plant and two pumpkin plants as its three rootstocks. }\end{array}$ \\
$\mathrm{T}_{7}$ & 1 watermelon/2 bottle gourd +1 pumpkin & $\begin{array}{l}\text { One watermelon plant was simultaneously grafted onto two bottle gourd } \\
\text { plants and one pumpkin plant as its three rootstocks. }\end{array}$ \\
$\mathrm{T}_{8}$ & 1 watermelon/3 bottle gourd & $\begin{array}{l}\text { One watermelon plant was simultaneously grafted onto three bottle gourd } \\
\text { plants as its three rootstocks. }\end{array}$ \\
\hline $\mathrm{T}_{9}$ & 1 watermelon $/ 3$ pumpkin & $\begin{array}{l}\text { One watermelon plant was simultaneously grafted onto three pumpkin } \\
\text { plants as its three rootstocks. }\end{array}$ \\
\hline Control & Self-rooted watermelon, as control. & \\
\hline
\end{tabular}

the fruit setting position. During fruit ripening and harvesting (30 days after pollination), 10 plants were randomly selected for testing the single fruit weight and the plot yield was measured. A digital refractometer (Atago, Japan) was used to test the soluble solids content in fruit. The titratable acid content was measured by titration with $\mathrm{NaOH}$, whereas the vitamin $\mathrm{C}$ content was tested by 2,6-dichlorophenol indophenol titration (Zhao et al., 2006).

\section{Statistical analysis}

Data were analysed with one-way ANOVA using SPSS version 19 (SPSS Inc., Chicago, IL) for Windows and means were compared with Duncan's multiple range test at 5\% level of significance.

\section{Results and discussions}

Effects of dual/threefold rootstock grafting on survival rate of watermelon seedlings

The results showed that the rootstock with varying amounts and different grafting combinations had significant effects on the survival rate of watermelon seedlings (Fig. 1). The

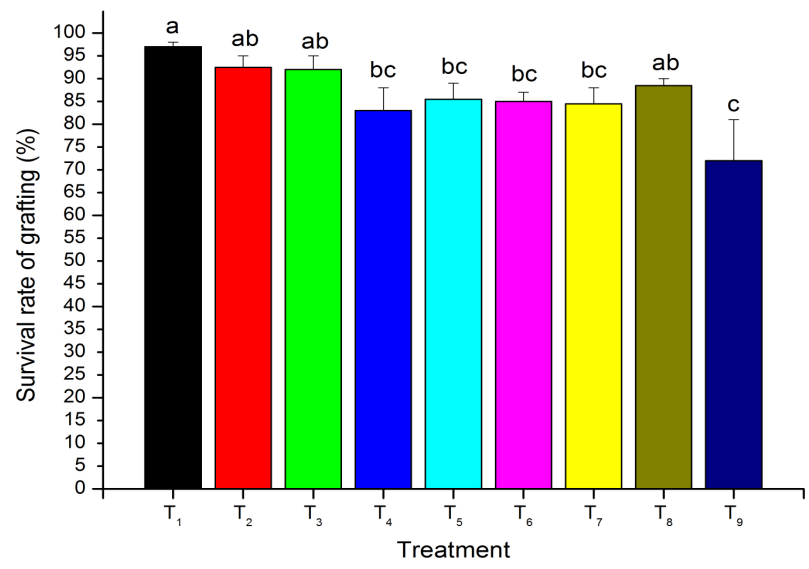

Fig. 1. Effects of single/dual/threefold rootstock grafting on survival rate of watermelon seedlings. Data with the different letter above the bars are significantly different at $\mathrm{P} \leq 0.05$ survival rates of bottle gourd $\left(T_{1}\right)$ and pumpkin $\left(T_{2}\right)$ during single rootstock grafting were above $90 \%$, indicating that both rootstock varieties had the best graft compatibility for watermelon. Except for the low survival rate of $T_{9}$ grafting, no significant differences were observed between the dual and threefold rootstock grafts in terms of the survival rate. The survival rates of the grafts $\left(T_{3}\right.$ and $\left.T_{8}\right)$ were not significantly lower than those of single rootstock grafting, which indicated that appropriate multi-rootstock grafting could similarly obtain a higher survival rate. The analytical results showed that the survival rate of the plants grafted with a pumpkin plant as rootstock varied with the amount of pumpkin rootstock. With the increasing quantity of pumpkin rootstocks, the survival rate of the grafted plants showed a downward trend. By varying the amount of bottle gourd as the rootstock, no significant differences were observed among the grafted plants in terms of their survival rate. Combined grafting with pumpkin and bottle gourd rootstocks did not have any significant interaction effects.

Yetisir et al. (2003a) observed that survival rate was high (95\%) in Lagenaria type rootstocks, while it was low (65\%) in Cucurbita type rootstocks. It was concluded that plant survival rates of grafted watermelon varied depending on rootstock characteristics and its compatibility with scion. In this study, the increased amount of rootstock made it difficult for the rootstock-scion section to heal, which consequently hindered plant survival. Although the survival rates of some multirootstock grafted treatments were lower than those of single rootstock grafting, both rates were still above $70 \%$.

\section{Effects of dual/threefold rootstock grafting on the growth of watermelon plants}

As shown in Tab. 2, the different grafted treatments had significant effects on stem diameter, number of leaves, Fv/Fm and $\Phi P S I I$ values of watermelon plants.

Several grafted treatments, namely, $\mathrm{T}_{8}, \mathrm{~T}_{3}, \mathrm{~T}_{9}, \mathrm{~T}_{5}$, and $\mathrm{T}_{7}$ had thicker stem diameters, whereas the control plants had the smallest stem diameter. The grafts $T_{3}$ and $T_{8}$ had the largest, whereas the control plants had the fewest number of leaves on all treatments. Some related reports suggest that grafting significantly affected plant growth. Grafted plants showed 
Tab. 2. Effects of different grafted treatments on the growth of watermelon plants

\begin{tabular}{lccccc}
\hline Treatment & Stem diameter $(\mathrm{cm})$ & $\begin{array}{c}\text { Number of leaves } \\
\text { (leaf/plant) }\end{array}$ & Fv/Fm & ФPS II & $\begin{array}{c}\text { Incidence of Fusarium } \\
\text { wilt(\%) }\end{array}$ \\
\hline $\mathrm{T}_{1}$ & $6.1 \mathrm{bcd}$ & $13.2 \mathrm{c}$ & $0.655 \mathrm{c}$ & $0.56 \mathrm{~cd}$ & $77 \mathrm{a}$ \\
$\mathrm{T}_{2}$ & $6.3 \mathrm{c}$ & $12.6 \mathrm{c}$ & $0.723 \mathrm{ab}$ & $0.62 \mathrm{abcd}$ & $10 \mathrm{~b}$ \\
$\mathrm{~T}_{3}$ & $8.6 \mathrm{a}$ & $24.0 \mathrm{a}$ & $0.752 \mathrm{ab}$ & $0.71 \mathrm{ab}$ & $0 \mathrm{~b}$ \\
$\mathrm{~T}_{4}$ & $5.6 \mathrm{~cd}$ & $13.7 \mathrm{c}$ & $0.703 \mathrm{abc}$ & $0.55 \mathrm{~d}$ & $53 \mathrm{a}$ \\
$\mathrm{T}_{5}$ & $7.4 \mathrm{ab}$ & $12.9 \mathrm{c}$ & $0.697 \mathrm{bc}$ & $0.64 \mathrm{abcd}$ & $7 \mathrm{~b}$ \\
$\mathrm{~T}_{6}$ & $6.7 \mathrm{bc}$ & $14.7 \mathrm{c}$ & $0.761 \mathrm{a}$ & $0.75 \mathrm{a}$ & $0 \mathrm{~b}$ \\
$\mathrm{~T}_{7}$ & $7.4 \mathrm{ab}$ & $20.0 \mathrm{~b}$ & $0.754 \mathrm{ab}$ & $0.69 \mathrm{abc}$ & $0 \mathrm{~b}$ \\
$\mathrm{~T}_{8}$ & $8.7 \mathrm{a}$ & $21.5 \mathrm{ab}$ & $0.707 \mathrm{abc}$ & $0.59 \mathrm{bcd}$ & $50 \mathrm{a}$ \\
$\mathrm{T}_{9}$ & $8.5 \mathrm{a}$ & $15.5 \mathrm{c}$ & $0.707 \mathrm{abc}$ & $0.63 \mathrm{abcd}$ & $17 \mathrm{~b}$ \\
$\mathrm{C}$ & $4.6 \mathrm{~d}$ & $8.5 \mathrm{~d}$ & $0.764 \mathrm{a}$ & $0.65 \mathrm{abcd}$ & $55 \mathrm{a}$ \\
\hline
\end{tabular}

Different letters between treatments denote significant differences (Duncan test, $\mathrm{P} \leq 0.05$ ).

Tab. 3. Effects of different grafted treatments on yield and quality of watermelon

\begin{tabular}{cccccc}
\hline Treatment & $\begin{array}{c}\text { Single fruit weight } \\
(\mathrm{kg})\end{array}$ & Plot yield $\left(\mathrm{kg} / 20 \mathrm{~m}^{2}\right)$ & $\begin{array}{c}\text { Total soluble solids } \\
\text { content }(\%)\end{array}$ & $\begin{array}{c}\text { Titratable acids } \\
\text { content }(\mathrm{g} / 100 \mathrm{ml})\end{array}$ & $\begin{array}{c}\text { Vitamin C content } \\
(\mathrm{mg} / 100 \mathrm{ml})\end{array}$ \\
\hline $\mathrm{T}_{1}$ & $0.65 \mathrm{~d}$ & $5.57 \mathrm{de}$ & $9.85 \mathrm{a}$ & $0.07 \mathrm{ab}$ & $4.97 \mathrm{abc}$ \\
$\mathrm{T}_{2}$ & $2.00 \mathrm{a}$ & $19.19 \mathrm{ab}$ & $7.53 \mathrm{~b}$ & $0.08 \mathrm{ab}$ & $3.08 \mathrm{c}$ \\
$\mathrm{T}_{3}$ & $1.22 \mathrm{c}$ & $15.64 \mathrm{abc}$ & $10.07 \mathrm{a}$ & $0.07 \mathrm{ab}$ & $6.47 \mathrm{ab}$ \\
$\mathrm{T}_{4}$ & $0.74 \mathrm{~d}$ & $11.71 \mathrm{bcd}$ & $9.32 \mathrm{a}$ & $0.06 \mathrm{~b}$ & $4.50 \mathrm{bc}$ \\
$\mathrm{T}_{5}$ & $1.67 \mathrm{~b}$ & $19.16 \mathrm{ab}$ & $8.43 \mathrm{ab}$ & $0.09 \mathrm{a}$ & $4.65 \mathrm{bc}$ \\
$\mathrm{T}_{6}$ & $1.29 \mathrm{c}$ & $19.08 \mathrm{ab}$ & $9.38 \mathrm{a}$ & $0.08 \mathrm{ab}$ & $7.97 \mathrm{a}$ \\
$\mathrm{T}_{7}$ & $1.17 \mathrm{c}$ & $22.16 \mathrm{a}$ & $9.17 \mathrm{ab}$ & $0.06 \mathrm{~b}$ & $5.40 \mathrm{abc}$ \\
$\mathrm{T}_{8}$ & $0.70 \mathrm{~d}$ & $8.05 \mathrm{cde}$ & $8.73 \mathrm{ab}$ & $0.07 \mathrm{ab}$ & $4.90 \mathrm{abc}$ \\
$\mathrm{T}_{9}$ & $1.67 \mathrm{~b}$ & $18.09 \mathrm{ab}$ & $8.37 \mathrm{ab}$ & $0.07 \mathrm{ab}$ & $3.87 \mathrm{bc}$ \\
\hline Control & $0.26 \mathrm{e}$ & $1.83 \mathrm{e}$ & $9.53 \mathrm{a}$ & $0.06 \mathrm{~b}$ & $6.50 \mathrm{ab}$ \\
\hline
\end{tabular}

Different letters between treatments denote significant differences (Duncan test, $\mathrm{P} \leq 0.05$ ).

more leaves, larger leaf area, thicker main stem diameter (Alan et al., 2007; Liu et al., 2003; Yetisir and Sari, 2003a) as compared with the control. Grafted plants on the rootstocks were more vigorous with significant higher yields in comparison with the non-grafted plants (Paroussi et al., 2007). The experiment of dual rootstock grafting with cucumber as the rootstock indicated that dual rootstock grafting was superior to single rootstock grafting in terms of the plant length, stem diameter, and number of leaves (Chu et al., 2010), consistent with our results.

The chlorophyll fluorescence parameters can be used to assess photosynthetic performance in vivo (Baker, 2008). Values of $\mathrm{Fv} / \mathrm{Fm}$ reflect the potential quantum efficiency of PS II and are used as a sensitive indicator of plant photosynthetic performance. ФPS II is the quantum yield of PS II photochemistry and can reflect the actual photochemical efficiency of PS II in the light (Maxwell and Johnson, 2000). In this study, the $\mathrm{Fv} / \mathrm{Fm}$ values of the leaves of differently grafted treatment plants were relatively low for $T_{1}$ and $T_{5}$. No significant differences were observed between the plants that were grafted in other treatments. The ФPSII of the leaves of plants grafted with bottle gourd as the rootstock $\left(T_{4}, T_{1}\right.$, and $T_{8}$ ) was low. No significant differences were observed between the plants grafted in other treatments. The $\mathrm{Fv} / \mathrm{Fm}$ and ФPSII values in the leaves of the plant with the combination of bottle gourd and pumpkin as its rootstock $\left(T_{6}, T_{3}\right.$, and $\left.T_{7}\right)$ were relatively high.

Generally, threefold rootstock grafting was superior to dual rootstock grafting, which was superior to single rootstock in terms of the stem diameter and the number of leaves, as well as the values of $\mathrm{Fv} / \mathrm{Fm}$ and ФPSII. The subsequent analysis showed that the combination of bottle gourd and pumpkin as rootstocks had significant positive interaction effects on the grafted watermelon plants in terms of the stem diameter and number of leaves, as well as the Fv/Fm and ФPSII values of the leaf.

The multi-rootstock grafted plants $\left(T_{3}, T_{6}\right.$, and $\left.T_{7}\right)$ showed no signs of wilting, whereas those with pumpkin as the rootstock had a lower incidence of wilting. Plants with the bottle gourd alone as rootstock $\left(T_{1}, T_{4}\right.$, and $\left.T_{8}\right)$ and the control plants had a higher incidence of wilting. Therefore, the disease resistance was higher with pumpkin as the rootstock than with bottle gourd. Grafts with pumpkin alone or with a combination of pumpkin and bottle gourd as rootstocks could significantly improve disease resistance. Disease resistance in grafted plants might be attributed entirely to the tolerance of the roots of the stock plants to soil-borne diseases. Yetisir et al. (2003b) found that all rootstocks and grafted plants used in their study were resistant to three known races of Fusarium oxyporum f.sp. niveum. The non-grafted plants showed the 
499

highest degree of disease incidence, while the grafted plants on all the rootstocks tested showed low disease incidence (Paroussi et al., 2007).

A comprehensive comparison showed that the grafted plant $\left(T_{3}\right)$ had the best growth potential, followed by the $T_{7}$ treatment. Meanwhile, the control plant had the poorest growth, whereas all the other plants that were grafted using other rootstocks had average growth potential.

\section{Effects of dual/threefold rootstock grafting on yield and quality of watermelon}

As shown in Tab. 3, the rootstock with varying amounts and different grafting combinations had significant effects on single fruit weight, plot yield, total soluble solids content, titratable acids content and vitamin $\mathrm{C}$ content of watermelon.

The plants with pumpkin alone as the rootstock $\left(T_{2}, T_{5}\right.$, and $T_{9}$ ) had the maximum mean single fruit weight, which was significantly greater than the mean single fruit weight of the grafted plants that used any other combination as the rootstock. The single fruit weight of the $T_{6}, T_{3}$, and $T_{7}$ treatments was significantly greater than those of plants that did not have pumpkin rootstocks. No significant differences were observed between the plants grafted with bottle gourd alone as the rootstock $\left(T_{1}, T_{4}\right.$, and $\left.T_{8}\right)$. However, these grafted plants were superior to the self-rooted watermelon in terms of the mean single fruit weight. This partially agrees with the results of Turhan et al. (2012) who reported that fruit weight was significantly influenced and increased by grafting as compared to the non-grafted plant. Miguel et al. (2004) also showed that the appropriate rootstock increased fruit size and improved yield stability compared to the nongrafted plants. In this study, differently grafted plants could be ranked based on the single fruit weight: plants grafted with pumpkin alone as rootstock > plants with pumpkin and bottle gourd as rootstock $>$ plants with bottle gourd alone as rootstock > self-rooted watermelon plants. Therefore, as long as the combined rootstock included the pumpkin plant, the mean single fruit weight would increase appreciably compared with the bottle gourd. However, the combination of pumpkin and bottle gourd as rootstocks had extremely significant negative interaction effects on the single fruit weight, which indicated that grafting with the combined pumpkin and bottle gourd rootstock might lower the single fruit weight. Previous studies on cucumbers have shown that the single fruit weight obtained by dual rootstock grafting was appreciably higher than that obtained by single rootstock grafting (Chu et al., 2010).

A comparison of all grafts that the plot yield of $T_{7}$ was significantly higher than that of $\mathrm{T}_{4}, \mathrm{~T}_{8}, \mathrm{~T}_{1}$ and control, without significant differences between the plot yield of $\mathrm{T}_{7}$ and that of $\mathrm{T}_{2}, \mathrm{~T}_{5}, \mathrm{~T}_{6}, \mathrm{~T}_{9}$ and $\mathrm{T}_{3}$. Differently grafted plants could be ranked based on the plot yield: plants grafted with pumpkin as rootstock $>$ plants with bottle gourd alone as rootstock $>$ selfrooted watermelon plants. Therefore, any plant grafted with pumpkin as its rootstock could remarkably increase its plot yield, whereas the bottle gourd as rootstock had a common effect. Sun and Lin (2014) reported that watermelons grafted onto Cucurbita type rootstocks produced higher yields than those onto Cucurbita type rootstocks. However, Yetisir and Sari (2003a) obtained the opposite result.

The different results may result from the use of different genotypes of rootstock or scion. The experiment on the dual rootstock grafting of cucumber showed that some types of dual rootstock grafting could significantly improve the yield compared with single rootstock grafting. However, some combinations did not have significant effects (Wang et al., 2011). Upon further analysis, the combination of pumpkin and bottle gourd as rootstocks had extremely significant interaction effects on the plot yield. The grafting of $\mathrm{T}_{7}$ with pumpkin and bottle gourd as the rootstock showed positive interaction effects, probably resulting in the higher yield obtained.

No significant differences were observed among most of the grafts and the control in terms of the soluble solids content in the harvested fruit. The soluble solids content of the grafted fruit with pumpkin as rootstock $\left(T_{2}, T_{5}\right.$, and $\left.T_{9}\right)$ was relatively low, which indicated that the soluble solids content was greatly affected. However, this value was less affected after the bottle gourd was added as the rootstock. Yetisir and Sari (2003a) found that soluble solids of watermelon were greatly affected by grafting, but the results were dependent on the rootstock used. Overall, grafting with bottle gourd or pumpkin alone as the rootstock will lower the soluble solids content in watermelon fruits, especially when grafting is performed with pumpkin alone as the rootstock (Alan et al., 2007; Alexopoulos et al., 2007). However, other studies have shown that the soluble solids content in watermelon fruits have no significant changes for grafting with pumpkin alone as the rootstock (Bekhradi et al., 2011; Colla et al., 2006; Huitrón-Ramírez et al., 2009). The differences in reported results may be attributable in part to type of rootstock/scion combinations used, different cultivation techniques and environmental conditions.

Our analysis of the different grafted plants revealed that the titratable acids content of fruits in $T_{5}$ was higher, whereas those in the $T_{4}$ and control were relatively lower. By contrast, the acidity of the watermelon fruit grafted with pumpkin as rootstock was higher, whereas that grafted with bottle gourd as rootstock was relatively lower. Grafting with either bottle gourd or pumpkin alone as rootstock could increase the titratable acid content of scion. Similarly, the miniwatermelon grafted onto the commercial hybrid rootstock 'PS 1313' (C. maxima $\times$ C. moschata) exhibited higher titratable acidity (Proietti et al. 2008)

A comparison of the vitamin $C$ content in fruits of the grafted plants showed that the vitamin $C$ content of $T_{6}$ was relatively high. The observed vitamin $C$ content for $T_{6}$ was appreciably higher than that of $T_{2}, T_{9}, T_{5}$, and $T_{4}$, and was not significantly different from the control group. Proietti $e t$ al. (2008) showed that total vitamin C contents for grafted mini-watermelon plants were higher $7 \%$ than those from ungrafted plants. The vitamin $\mathrm{C}$ content in the watermelon fruit from the plant grafted with a combination of bottle gourd and pumpkin as its rootstock was higher than that of plants grafted with bottle gourd or pumpkin alone as rootstock. The vitamin $\mathrm{C}$ content with bottle gourd alone as the rootstock was higher than with pumpkin alone as the rootstock. This trend is inconsistent with the earlier result that no significant differences were found between the dual rootstock and single rootstock grafting in terms of the vitamin C content in the fruits of cucumber plants (Chu et al., 2010). The effects of the combination of bottle gourd and pumpkin as the rootstock on the vitamin $\mathrm{C}$ content showed extremely significant positive interaction effects, which 
indicated that the combination of the two rootstock varieties increased the vitamin $\mathrm{C}$ content.

\section{Conclusions}

The plant growth, yield, and quality of the multirootstock grafted plant were related to the variety and combination of rootstock. The appropriate dual/threefold rootstock grafting could enhance the growth potential of plants and lower the incidence of wilt with relatively high plot yield, soluble solids and vitamin $\mathrm{C}$ content in fruit. The effects of combined rootstock on the plant growth, yield and quality of the scion partially showed the interaction effects and the complementation of differences between the rootstocks. The multi-rootstock grafting of watermelon is feasible.

\section{Acknowledgments}

This work was supported by the technical innovation engineering project of Sichuan province (063z1700).

\section{References}

Alan O, Zdemir N, Nen Y (2007). Effect of grafting on watermelon plant growth, yield and quality. J Agron 6(2):362365.

Alexopoulos A, Kondylis A, Passam HC (2007). Fruit yield and quality of watermelon in relation to grafting. J Food Agric Env 5(1):178-179.

Baker NR (2008). Chlorophyll fluorescence: a probe of photosynthesis in vivo. Annu Rev Plant Biol 59:89-113.

Bekhradi F, Kashi A, Delshad M (2011). Effect of three cucurbits rootstocks on vegetative and yield of 'Charleston Gray' watermelon. Int J Plant Prod 5(2):105-109.

Chouka AS, Jebari H (1999). Effect of grafting on watermelon on vegetative and root development, production and fruit quality. Acta Hortic 492:85-93.

Chu ZS, Chen HL, Wu Z, Lui MC (2010). Effects of doublestock grafting on the growth, yield and quality of cucumber in greenhouse. China Veg (8):14-20.

Colla G, Rouphael Y, Cardarelli M, Rea E (2006). Effect of salinity on yield, fruit quality, leaf gas exchange, and mineral composition of grafted watermelon plants. HortScience 41(3):622-627.

Davis A R, Perkin-Veazie P, Hassell R Levi A, King SR, Zhang XP (2008a). Grafting effects on vegetable quality. HortScience 43(6):1670-1672.

Davis A R, Perkins-Veazie P, Sakatab Y, López-Galarza S, Maroto JV, Lee SG, Huh YC, Sun ZY, Miguel A, King SR, Cohen R, Lee JM (2008b). Cucurbit grafting. Crit Rev Plant Sci 27(1):50-74.
Huitrón-Ramírez M V, Ricárdez-Salinas M, Camacho-Ferre F (2009). Influence of grafted watermelon plant density on yield and quality in soil infested with melon necrotic spot virus. HortScience 44(7):1838-1841.

Lee JM (1994). Cultivation of grafted vegetables I. Current status, grafting methods, and benefits. HortScience 29(4):235-239.

Lee JM, Oda M (2002). Grafting of herbaceous vegetable and ornamental crops. Hortic Rev 28:61-124.

Liu R Q, Zhang H M, Xu J H, Huang DF, Yao FJ (2003). Effects of rootstocks on growth and fruit quality of grafted watermelon. J Shanghai Jiaotong Univ (Agricultural Science) 21(4):289-294.

Maxwell K and Johnson GN (2000). Chlorophyll fluorescence-a practical guide. J Exp Bot 51(345):659-668.

Miguel A, Maroto JV, San Bautista A, Baixauli C, Cebolla V, Pascual B, López S , Guardiola JL (2004). The grafting of triploid watermelon is an advantageous alternative to soil fumigation by methylbromide for control of Fusarium wilt. Sci Hortic 13(1):9-17.

Paroussi G, Bletsos F, Bardas G A, Kouvelos J A, Klonari A (2007). Control of Fusarium and Verticillium wilt of watermelon by grafting and its effect on fruit yield and quality. Acta Hotic 729:281-285.

Proietti S, Rouphael Y, Colla G, Cardarelli M, de Agazio M, Zacchini M, Moscatello S, Battistelli A (2008). Fruit quality of mini-watermelon as affected by grafting and irrigation regimes. J Sc Food Agric 88(6):1107-1114.

Rouphael Y, Schwarz D, Krumbein A, Colla G (2010). Impact of grafting on product quality of fruit vegetables. Sci Hortic 127(2):172-179.

Sun XX, Lin HM (2014). Effects of different stocks and matching cultivation technology on watermelon yield and quality under plastic tunnel. China Veg (4):37-40.

Turhan A, Ozmen N, Kuscu H, Serbeci MS, Seniz V (2012). Influence of rootstocks on yield and fruit characteristics and quality of watermelon. Hortic Env Biotechnol 53(4):336-341.

Wang TC, Wang HR, Zhao SC, Li HL, Chi MN, Wang SK (2011). Preliminary report about effects of cucumber grafted with different double rootstocks on growth, yield and wax powders characters. China Veg (6):54-57.

Yetisir H, Sari N (2003a). Effect of different rootstock on plant growth, yield and quality of watermelon. Aust J Exp Agric 43(10):1269-1274.

Yetisir H, Sari N, Yucel S (2003b). Rootstock resistance to Fusarium wilt and effect on watermelon fruit yield and quality. Phytoparasitica 31(2):169-175.

Zhao XM, Jiang Y, Wu YP, Liu K, Zhang ZQ (2006). Assay research on $\mathrm{Vc}$ content in fruit and vegetable. Food Sci 27(3):197-199. 